\title{
SURGICAL TREATMENT OF CONGENITAL TORTICOLLIS, AT THE SHRINERS HOSPITAL, MEXICO CITY
}

\author{
TRATAMENTO CIRÚRGICO DE TORCICOLO CONGÊNITO NO HOSPITAL SHRINERS, \\ CIDADE DO MÉXICO
}

\section{TRATAMIENTO QUIRÚRGICO DE TORTÍCOLIS CONGÉNITO EN EL HOSPITAL SHRINERS, CIUDAD DE MÉXICO}

Antonio Hurtado Padilla', José Antonio Canales Najera', Alejandro Dabaghi Richerand', Paulo Roberto Cabrera Ortiz ${ }^{1}$

1. Hospital Shriners para Niños, Scoliosis Clinic, Ciudad de México, Distrito Federal.

\begin{abstract}
Objective: This study aims to evaluate the outcome of surgical treatment of congenital torticollis in our hospital. Methods: We collected the medical records of all patients diagnosed with congenital torticollis in the last 3 years at Shriners Hospital, Mexico City. The cases of congenital torticollis treated with surgery were selected and we evaluated the type of surgical technique, bleeding, time of surgery and complications, as well as the associated diagnoses of hip dysplasia. Results: We found 11 patients, of whom 7 met the inclusion criteria. Three women and four men with mean age of 10.7 years, five of whom had right, and two left side affections. All were surgically treated, five with unipolar and two with bipolar release. The surgery time was similar in both techniques and no complications were found in any of the groups. In two cases there were associated diagnoses, Klippel-Feil syndrome and congenital talipes equinovarus (CTEV) in one and psychomotor retardation in another. No association was found with hip dysplasia. All patients had improved range of movement and head tilt. There were no complications related to the surgical procedure or need for reintervention in our patients. Conclusions: Surgical treatment of congenital torticollis by uni- or bipolar release is an effective and safe method for these patients, presenting aesthetic and functional benefits.
\end{abstract}

Keywords: Torticollis/congenital; Tenotomy; Surgical procedures, operative.

\section{RESUMO}

Objetivo: Este estudo visa avaliar o resultado do tratamento cirúrgico de torcicolo congênito em nosso hospital. Métodos: Foram coletados os registros de todos os pacientes com diagnóstico de torcicolo congênito nos últimos 3 anos no Hospital Shriners, Cidade do México. Selecionaram-se os casos de torcicolo congênito tratados com cirurgia, avaliando-se tipo de técnica cirúrgica, sangramento, tempo de cirurgias e complicações, assim como os diagnósticos associados e a presença de displasia de quadril. Resultados: Foram encontrados 11 pacientes, dos quais 7 satisfizeram os critérios de inclusão. Três mulheres e quatro homens com média de idade de 10,7 anos, dos quais, cinco tinham afecção do lado direito e dois do lado esquerdo. Todos foram tratados cirurgicamente, cinco com liberação unipolar e dois com bipolar. O tempo de cirurgia foi semelhante nas duas técnicas e não se constataram complicações em nenhum dos grupos. Em dois casos havia diagnósticos associados, síndrome de Klippel-Feil e pé torto equinovaro (PTC) em um e atraso psicomotor em outro. Não se encontrou associação com displasia de quadril. Todos apresentaram melhoras da amplitude de movimento e da inclinação da cabeça. Não houve complicações relacionadas com o procedimento cirúrgico nem necessidade de reintervenção em nossos pacientes. Conclusões: 0 tratamento cirúrgico do torcicolo congênito por liberação uni ou bipolar é um método efetivo e seguro para esses pacientes, apresentando benefício estético e funcional.

Descritores: Torcicolo/congênito; Tenotomia; Procedimentos cirúrgicos operatórios.

\section{RESUMEN}

Objetivo: El objetivo de este estudio es evaluar el resultado del tratamiento quirúrgico del tortícolis congénito en nuestro hospital. Métodos: Se recabaron todos los pacientes con diagnóstico de tortícolis congénito en los últimos 3 años en el Hospital Shriners, ciudad de México. Se seleccionaron los casos de tortícolis congénito tratados quirúrgicamente, valorando el tipo de técnica quirúrgica, sangrado, tiempo quirúrgico y complicaciones, así como diagnósticos asociados y la presencia de displasia de cadera. Resultados: Se encontraron 11 pacientes de los cuales 7 cumplieron con los criterios de inclusión. Tres mujeres y cuatro hombres con un promedio de edad de 10.7 años, en los cuales cinco tenían afección en el lado derecho y dos en el izquierdo. Todos fueron manejados quirúrgicamente, cinco con liberación unipolar y dos con bipolar. El tiempo quirúrgico fue similar para las dos técnicas y no se encontraron complicaciones en ninguno de los grupos. En dos casos existieron diagnósticos asociados, síndrome de Klippel-Feil y pie equino varo congénito (PEVC) en uno y retraso psicomotor en otro. No se encontró asociación con displasia de cadera. Todos presentaron mejoría de los arcos de movilidad y de la inclinación de cabeza. No hubo complicaciones relacionadas al procedimiento quirúrgico ni necesidad de reintervenciones en nuestros pacientes. Conclusiones: El tratamiento quirúrgico del tortícolis congénito mediante liberación uni o bipolar es un método efectivo y seguro para estos pacientes, presentando un beneficio estético y funcional.

Descriptores: Tortícolis/congénito; Tenotomía; Procedimientos quirúrgicos operativos. 


\section{INTRODUCTION}

Congenital torticollis occurs in $1-2 \%$ of the population, clinically presented as a lateral inclination of the head accompanied by the rotation of the chin to the opposite side. There are several causes, such as bone abnormalities of the spine like the Klippel-Feil syndrome, congenital scoliosis, occipitocervical fusion, odontoid process malformations, ocular changes, gastroesophageal reflux like the Sandifer syndrome, and benign paroxysmal torticollis. Fibrosis of the sternocleidomastoid muscle is the main cause of the presentation of congenital torticollis. ${ }^{1}$

In most cases of congenital muscular torticollis, the diagnosis is established starting at two months of age. The right side is more frequently affected, by a factor of three to one, and it is more prevalent in males than in females. Several pathologies have been associated with it, such as dysplasia in hip development, facial and cranial asymmetries, and metatarsus varus. ${ }^{1-3}$

The initial evaluation of a patient with congenital torticollis should pay attention to abnormalities that could have derived from the sternocleidomastoid muscle, trauma to the shoulder or skull during birth, neurological deficit, visual and auditory changes, and facial asymmetry. In congenital muscular torticollis, a mass in the lower third of the sternocleidomastoid muscle can be palpated that generally decreases in size during the first few months of life..$^{1,2}$

When there is no clear evidence of a mass in the sternocleidomastoid muscle or any suspicion of congenital changes of the cervical spine, the use of radiography, tomography, or magnetic resonance studies is recommended. Ultrasound can be used to differentiate any evidence of a fibroid tumor at the muscular level, as well as, as a tool for follow-up of conservative treatment. ${ }^{1,2}$

In the management of congenital muscular torticollis, the initial treatment should be performed with physical therapy in the home and good results have been reported in patients less than one year old. Starting treatment prior to 4 months of age yields better results. The outcomes are better in contractions of less than 10-15 degrees. If there is no improvement within the first four weeks of treatment, it is recommended that the patient undergo directed professional physical therapy. ${ }^{4}$

Untreated congenital muscular torticollis may cause facial and cranial asymmetry accompanied by a limited range of movement. ${ }^{5,6}$

Among the surgical options are percutaneous tenotomy, Z-plasty, unipolar or bipolar resection of the sternocleidomastoid muscle, as well as endoscopy-assisted tenotomy and radical muscle resections. Surgical treatment is indicated for patients older than one year of age who have not improved with conservative treatment. Surgical procedures achieve good clinical and functional results and improve facial and cranial asymmetry when the patient is younger than 5 years of age, however remodeling of the asymmetry can be seen in patients up to 10 years of age. .,7,8 $^{\text {y }}$

Bipolar resection has been reported with good results in patients older than 10 years of age, with improved range of movement, but poor modeling of facial and cranial asymmetry. This type of procedure may be accompanied by Z-plasty.,

The objective of this study is to evaluate the results of surgical treatment by unipolar or bipolar tenotomy in patients with congenital muscular torticollis, as well as the surgical time and associated complications.

\section{METHODS}

We collected the records of patients diagnosed with congenital muscular torticollis who underwent surgical treatment during the last three years at the Hospital Shriners para niños in Mexico City.

Age, sex, affected side, type of surgical procedure performed, surgical time, complications associated with the treatment, and associated pathologies or illnesses were recorded.

The efficacy of the treatment was assessed according to the improvement in the range of movement and the absence of complications related to the procedure.
We used SPSS version 21 to perform the descriptive analysis of the variables with frequencies and percentages.

The study was authorized by the Department of Teaching and Research of the Hospital Shriners para niños, Mexico City, with the consent of the patients.

\section{RESULTS}

We found 11 patients who underwent surgical intervention over the last three years. Of these, 7 met the inclusion criteria.

The average age was 10.7 years. Four patients (57.1\%) were males and in $71.4 \%$ of the cases, the right side was affected. (Table 1)

In terms of the type of surgical treatment, five patients (71.4) underwent unipolar release of the sternocleidomastoid muscle and two underwent bipolar release. None of the patients was treated with Z-plasty. (Figure 1)

The surgical time of the procedure was similar for both types of treatment and no case had associated complications.

Two cases had an added diagnosis of Klippel-Feil Syndrome, one with a congenital clubfoot and one with mild locomotor retardation.

All patients showed improvements in range of movement and lateral inclination of the head. None of the patients required revision surgery.

\section{DISCUSSION}

The results of the treatment of congenital muscular torticollis depend greatly on the age at which management is started. Conservative treatment is effective in patients less than one year old. Surgical procedures are reported to have better outcomes in patients under 5 years of age and in those who undergo a rigorous postoperative program of physical therapy. There is no consensus regarding postoperative immobilization.

Table 1. Patients with congenital torticollis

\begin{tabular}{c|c|c|c|c}
\hline Case & Age & Sex & Side affected & Release \\
\hline 1 & 11 & M & Right & Bipolar \\
\hline 2 & 16 & F & Right & Bipolar \\
\hline 3 & 9 & M & Right & Unipolar \\
\hline 4 & 12 & F & Left & Unipolar \\
\hline 5 & 11 & M & Left & Unipolar \\
\hline 6 & 2 & F & Right & Unipolar \\
\hline 7 & 14 & M & Right & Unipolar \\
\hline
\end{tabular}
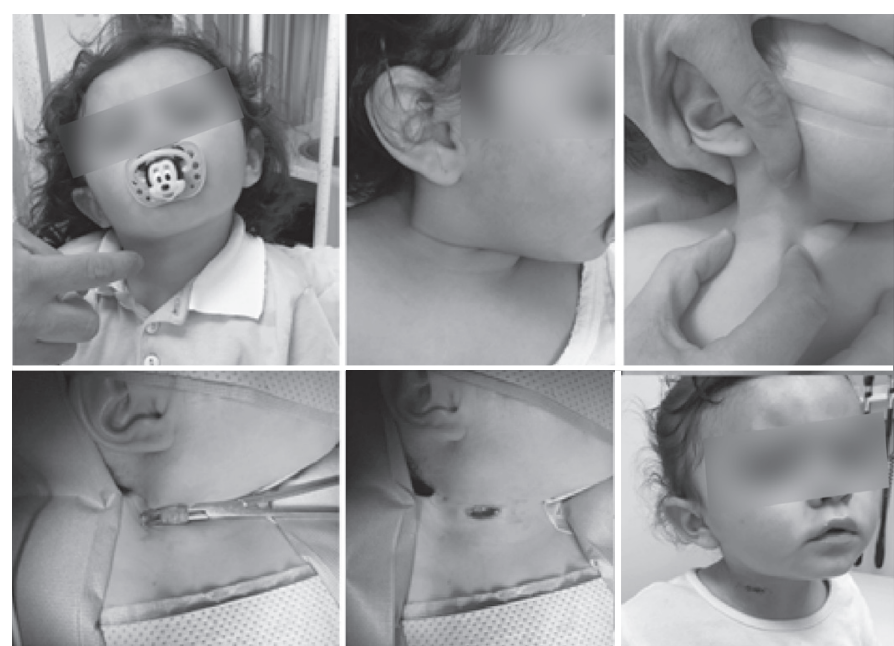

Figure 1. Unipolar release. Female patient with right-side congenital torticollis. Unipolar release of the right sternocleidomastoid was performed. Final result. 
Shim and Jang, ${ }^{10}$ in their study of 47 patients, reported a higher prevalence of involvement of the right side. Thirty-seven of them underwent unipolar tenotomy and 10 underwent bipolar tenotomy. They reported similar results for both groups, however, postoperative rehabilitation was considered the most important factor in the clinical and functional outcomes. In our study, we observed similar functional results in the groups of patients treated with unipolar and bipolar tenotomy.

Ekici et al., ${ }^{11}$ in their study of 6 children older than 5 years of age treated with Z-plasty, reported excellent clinical and functional results. In our study, no patient was considered for Z-plasty of the sternocleidomastoid muscle.

The average age in our study was 10.5 years and the type of resection was not influenced by age. Sudesh et al. ${ }^{9}$ reported 14 patients, older than 10 years of age, who underwent bipolar tenotomy, for whom this type of resection was considered to enable better results than unipolar tenotomy. However, there was no control group.

We consider some of the limitations in our study to be the fact that it is a retrospective study of a series of cases over a short period of time without long-term follow-up of the results.

\section{CONCLUSIONS}

Unipolar or bipolar release in the treatment of congenital muscular torticollis is an effective and safe method for those patients, offering cosmetic and functional benefits.

All authors declare no potential conflict of interest related to this article.

CONTRIBUTION OF THE AUTHORS: AHP, JACN, ADR, PRCO participated in the realization of the article.

\section{REFERENCES}

1. Martin J. HermaN, Michael Wolf. Torticollis in Children. Urr Orthop Pract 2013;24(6):598-63.

2. Dudkiewicz I, Ganel A, Blankstein A. Congenital muscular torticollis in infants: ultrasoundassisted diagnosis and evaluation. J Pediatr Orthop. 2005;25(6):812-4.

3. Al Kaissi A, Ben Chehida F, Safi H, Nassib N, Ben Ghachem M, Gharbi H, et al. Progressive congenital torticollis in VATER association syndrome. Spine (Phila Pa 1976). 2006;31(12):E376-8.

4. Suhr MC, Oledzka M. Considerations and intervention in congenital muscular torticollis. Curr Opin Pediatr. 2015:27(1):75-81.

5. Seo SJ, Kim JH, Joh YH, Park DH, Lee IJ, Lim H, et al. Change of Facial Asymmetry in Patients With Congenital Muscular Torticollis After Surgical Release. J Craniofac Surg. 2016;27(1):64-9.

6. Lepetsos P, Anastasopoulos PP, Leonidou A, Kenanidis E, Flieger I, Tsiridis E, et al. Surgical management of congenital torticollis in children older than 7 years with an average 10-year follow-up. J Pediatr Orthop B. 2016 May 19. [Epub ahead of print] PubMed PMID: 27203708.

7. Shim JS, Noh KC, Park SJ. Treatment of congenital muscular torticollis in patients older than 8 years. J Pediatr Orthop. 2004;24(6):683-8.

8. LeeTG, Rah DK, Kim YO. Endoscopic-assisted surgical correction for congenital muscular torticollis. J Craniofac Surg. 2012:23(6):1832-4.

9. Sudesh P, Bali K, Mootha AK, Dhillon MS. Results of bipolar release in the treatment of congenital muscular torticolis in patients older than 10 years of age. J Child Orthop. 2010;4(3):227-32.

10. Shim JS, Jang HP. Operative treatment of congenital torticollis. J Bone Joint Surg Br. 2008:90(7):934-9

11. Ekici NY, Kizilay A, Akarcay M, Firat Y. Congenital muscular torticollis in older children: treatment with Z-plasty technique. J Craniofac Surg. 2014;25(5):1867-9. 